\title{
IMPLEMENTING MULTICULTURAL VALUES OF STUDENTS THROUGH RELIGIOUS CULTURE IN ELEMENTARY SCHOOL ISLAMIC GLOBAL SCHOOL MALANG CITY
}

\author{
Ach Fikri Fausi \\ Email: fikrifausi93@gmail.com \\ Elementary School Islamic Global School Malang
}

\begin{abstract}
The internalization of multicultural values is carried out as an effort to introduce the diversity of Indonesian society. This means that the internalization of multicultural values wants to provide planting for students to respect and have good humanistic qualities among their peers. Internalization of values is a way to introduce diversity and differences to students without questioning the differences that each student has. From the results of observations at SD-Islamic Global School Malang City, educators has properly applied multicultural internalization to students through religious culture. This discovery aims to obtain concrete, definite and accountable clarity regarding the internalization of multicultural values to students through religious culture in SD-Islamic Global School Malang City. This study aims to: 1) Understand the religious culture model in SD-Islamic Global School Malang City, 2) identify multicultural values internalized through religious culture in SD Islamic Global School Malang City, and 3) describe the process of internalizing multicultural values through religious culture in SD Islamic Global School Malang City. To achieve this goal, this study used a qualitative research approach by selecting the background of SD Islamic Global School Malang, then the researcher used a case study research type. The results showed that: 1) Religious culture model in SD-Islamic Global School Malang City is divided into two types, namely: a) the value of devotion to God, and b) human values. 2) There are two types of multicultural values internalized through religious culture in SD-Islamic Global School Malang, namely: a) democratic values. b) The value of tolerance, 3) The process of internalizing the multicultural values of students through religious culture at SD-Islamic Global School Malang: a) role models, teachers b) habits, and c) through Standard Operating Procedures (SOP).
\end{abstract}

Keywords: Internalization, Multicultural Values, and Religious Culture 
IJIERM: Vol. 2 No. 1 Januari - April 2020

\section{PRELIMINARY}

Cultural diversity, especially the diversity of religions, ethnicities and races, has directly or indirectly presented many challenges for mankind. One of the consequences is the potential for conflict to conflict with one another. In almost all countries there are violent conflicts between citizens of different backgrounds, either due to differences in beliefs (religion / religious organization), ethnicity, race, color, or other differences.

Violence against the background of the above differences also occurs in schools or educational institutions which in fact are places to improve character and understanding of how to socialize, gather with the community (peers) and respect each other, but in fact it is in educational institutions. There are still many recorded problems related to sociocultural problems. As noted and determined by the United Nations, 75 percent of the major conflicts that occur in the world today are rooted in cultural dimensions. ${ }^{1}$

Educational institutions are expected to instill attitudes in students to respect other people, cultures, religions and beliefs. With the hope that the implementation of multicultural values will bring students to understand, accept and respect other people who are of different ethnicities, cultures and personality values. Through multicultural values that are carried out in schools, It will become a habitual training for the young generation to accept differences in culture, religion, race, ethnicity and needs among others and want to live together in peace. This is in line with the Constitution No. 20 Article 4 of 2003 concerning the National Education System states That education is carried out in a democratic, non-discriminatory manner by upholding human rights, religious values, cultural values and National Education System states that education is carried out in a democratic, non-discriminatory manner by upholding human rights, religious values, cultural values and national diversity. ${ }^{2}$

SD-IGS are a basic education institution that cultivates religious activities, this is an effort to instill multicultural values in students, through religious activities that are packaged in groups and civilize them, as conveyed by Mr. Fahmi as teacher of Islamic Education at SD -IGS as follows:

"Cultivating multicultural values in students in this institution, we do it by applying religious culture. With the hope that students will be able to take lessons from the religious activities that we apply and get used to, so that they become accustomed to it in everyday life. Apart from that, we are implementing this religious culture, not only one or two teachers who play 
a role, but all parties in the school environment play an active role and have responsibility for these activities. "3

The same thing was conveyed by one of the class $1 \mathrm{C}$ teachers that the religious habits carried out in this school are expected to be able to make students have skills such as respecting fellow friends, respecting teachers, not differentiating from one another, disciplined, regular, and able to be personal. Both on the side of society and with Allah, meaning good to society and good to Allah. ${ }^{4}$

Educational institutions have a very strategic role in fostering multicultural attitudes. The religious cultures mentioned above have also been implemented in SD-IGS. This can be seen from the plurality of students, and existing teachers and employees. In the midst of this plurality, socialization and communication between its components are well established. In addition, the majority of students come from the middle and upper class. However, school residents at SD-IGS never looked at the status of individuals or groups, or, from what ethnicity, when they socialized so that their academic achievement was not disturbed by the differences that existed between them. ${ }^{5}$

Based on temporary observations conducted by researchers, it shows that the internalization of multicultural values in the institution is carried out using a cultural strategy, namely making religious values a culture, as stated by Mr. Susanto as Deputy principal of the curriculum section that:

"The multicultural values that we instill through this religious culture include: (1). The habit of praying in congregation starts from grade 1 to grade 6 , while the lessons that can be taken are how to live in groups (socially), discipline, values of solidarity, togetherness, eliminating envious thoughts and prejudice. (2). Pray before entering class and pray before the lesson begins by taking turns being the leader, (the multicultural value is how to live in groups that respect and be democratic) (3). Take turns to call to prayer and become the prayer priest, (4). Memorization of short letters, prayers and prophetic hadiths. "6

Based on this, he explained that even though they were different, they had multicultural values that were good and wise, for example, the little thing that he demonstrated was when one of them forgot to bring a book. Lesson then

${ }^{1}$ Https://www.google.co.id/amp/s/nasional tempo.co/amp

${ }^{2}$ Undang-Undang Sisdiknas Nomor 20 Tahun 2003, tentang Sistem Pendidikan Nasional, (Bandung: Citra Umbara, 2009), p. 64.

${ }^{3}$ Fahmi, Interview (Kota Malang, 21 Februari 2019). 
spontaneously one of them responds by sharing. This is proof that their multicultural values are quite good and wise, because of the habits practiced by us as classroom teachers and also, family and school policies, and religious activities.

It is hoped that this will become a habit for students in everyday life and can take social lessons from the values of these religious activities.

\section{LITERATURE REVIEW}

Literally, internalization is an appreciation of the process of teachings, doctrines or values so that they realize the belief in the truth of doctrines or values that are manifested in attitudes and behavior. Internalization is a stage of remodeling the results of objectivity by changing the structure of the outer environment into the structure of the inner environment, namely subjective awareness. $^{7}$

Meanwhile, the meaning of value in English comes from the word value, comes from the Latin valere or ancient French flair. In terms of denotative meaning, valere, valoir, value can be interpreted as price. There is a price in the interpretive sense, for example the value of diamonds, the price of money, intelligence figures, grades or qualities and characteristics or things that are important or useful to humanity. ${ }^{8}$

According to Sidi Gazalba, value is something abstract, it is ideal. Value is not a concrete object, not a fact that is not only a matter of right and wrong, which demands empirical proof, but a matter of appreciation that is desired and unwanted, liked and disliked. ${ }^{9}$

Noeng Muhajir defines value as something normative, something that is striving for or should be achieved, fought for and enforced. The value is something that is ideal, not factual, so that its translation or operation requires interpretation. ${ }^{10}$

Definition according to Fraenkel: "value is an idea, a concept about what someone thinks is important in life". Value is a conceptual idea of what a person thinks is important in life. ${ }^{11}$

According to Driyakara, the value is: "The essence of something that causes it to be pursued by humans". 12

Meanwhile, the meaning of value according to Chabib Thoha, "The essence attached to something that is very meaningful to human life". ${ }^{13}$

${ }^{4}$ Eni, Interview (Kota Malang, 27 Februari 2019)

5 Susanto, Interview (Kota Malang, 15 Desember 2018).

'Susanto, Interview (Kota Malang, 15 Desember 2018). 
Value internalization is the process of making values a part of oneself. This process will be created when the atmosphere, environment and human interaction are created which allows the process of questioning and internalizing values to occur. ${ }^{14}$

\section{Types of Values}

Value when viewed in terms of classification is divided into various types, including:

1) In terms of the main components of Islamic teachings as well as the highest value of Islamic teachings, the scholars divide the values into three parts, namely: the value of faith (faith), the value of worship (Sharia), and the value of morals (Ihsan). This classification is based on the explanation of the Prophet Muhammad SAW to the Angel Jibril regarding the meaning of Iman, Islam and Ihsan, which are essentially the same as creed, shari'ah and morals.

2) Judging from the source, the value is divided into two, namely the value that comes down from Allah SWT, which is called divine value and the value that grows and develops from human civilization itself which is called human value. These values then from the norms or rules of life that are followed and institutionalized in the society that supports them. ${ }^{15}$

3) Then in the value theory, analysis there are two types of educational values, namely: (1) Instrumental value, namely the value that is considered good because it is valuable for something else, (2) intrinsic value, namely

${ }^{7}$ Dhita Pramasanti, "Internalisasi Nilai-nilai keagamaan dalam membentuk komonikasi keluarga islami di era digital", Jurnal Interferensi, Vol. 12 no.01, Juni 201804

8 Tim Redaksi kamus besar bahasa Indonesia Edisi kedua, Kamus Besar Bahasa Indonesia, (Jakarta: Balai Pustaka,1995), cet.4, p. 690.

${ }^{9}$ Sidi Gazalba, Sistematika Filsafat, buku IV, (Jakarta: Bulan Bintang, 1978), p. 20.

${ }^{10}$ Noeng Muhajir, Pendidikan Ilmu dan Islam, (Yogyakarta: Reka Sarasin, 1985), p. 11- 12.

${ }^{11}$ J.R. Fraenkel, How to teach about Values: an Analitic Approach, (New Jersey: Preteice Hall, inc.1975),P.6

12 A. Atmadi dan Y. setyaningsih, (eds.), Pendidikan Nilai Memasuki Milenium Ketiga, (Yogyakarta: Kanisius, 2004 cet. 5,), p. 72.

${ }^{13}$ Chabib Thoha, Kapita Selekta Pendidikan Islam, (Yogyakarta: Pustaka Pelajar, 1996), p. 62.

${ }^{14}$ Soediharto, Menuju Pendidikan Nasional yang Relevan dan Bermutu, (Jakarta: Balai Pustaka, 1993 , cet. 4.

${ }^{15}$ Ramayulis, Ilmu Pendidikan Islam, (Jakarta: KALAM MULIA, 2012), p. 250

${ }^{16}$ Muhammad Nur Syam, Pendidikan Filsafat dan Dasar Filsafat Pendidikan, (Surabaya: Usaha Nasional, t.t)

${ }^{17}$ Ahmad Tafsir,Filsafat Pendidikan Islam...., p. 230-231 
IJIERM: Vol. 2 No. 1 Januari - April 2020

the value that is considered not good for something else but inside and himself. 16

\section{Internalization Method / Technique}

In internalizing multicultural values to students through religious culture has methods or techniques, such as:

1) Exemplary: Exemplary is very effective for internalizing values, because psychologically students like to imitate and social sanctions, that is, someone will feel guilty if he does not imitate the people around him. In Islam, even example is very privileged to call that the Prophet was a good role model (uswah hasanah). Prophets and God set the example of the Prophet. ${ }^{17}$

2) Habit: hospitalization is the stabilization and the institutionalization of the values of faith in students, which begins with spiritual and physical actions. The habit can be done programmed in learning and not programmed in daily activities.

3) Association: through association, educators communicate the noble values of religion, either by way of discussion or question and answer. Thus, their insight into the values of multicultural education will be well internalized, because this close association will make them not feel any gaps.

4) Rule Enforcement: discipline enforcement is usually related to rule enforcement. Ideally, in enforcing rules, it should be directed to "Fear of rules, not fear of people". When this grows in awareness it creates comfortable and safe conditions. ${ }^{18}$

\section{Understanding Multicultural}

The root of the word multiculturalism is culture. Etymologically, multiculturalism is formed from the word multi (many), culture (culture), and ism (flow / understanding). ${ }^{19}$ Banks defines the notion of multiculturalism in his book entitled Race, Culture and Education: "The variabel names used to describe the reform movements reflect the myriad goals and strategies that have been used to respond to the ethnic movements both within and across different nations' 20 Multiculturalism is a discourse that recognizes the existence of many ethnic groups with different cultures within a region or country. ${ }^{21}$

Clarifying the statement from Banks, Mulkhan stated that multiculturalism is an idea that is born from the fact that differences among citizens are originated from ethnicity along with the birth of history, different life experiences create 
awareness and different values that sometimes appear contradictory. ${ }^{22}$ Harahap defines Multiculturalism as ideas, perspectives, policies, attitudes and actions, by society a country, which is diverse in terms of ethnicity, culture, religion and so on, but has aspirations to develop the same national spirit and has pride in maintaining this plurality. ${ }^{23}$

\section{Multicultural Foundations}

Initially, the dissemination of multicultural discourse through various affirmative action activities aimed at rejecting anti-racism and discrimination was then continued by disseminating the concept of multiculturalism in the form of teaching and education in schools. ${ }^{24}$ Multicultural discourse has found its momentum since the 1970s, after previously developing "intercultural education" in the US, dealing with the increasing "multiculturalism" in these countries. The seriousness of the US government, for example, in multicultural studies was warmly welcomed by intellectuals, as reflected in the "melting pot" theory and the "salad bowl" theory which had been developed, although both of them ultimately failed. 25

Multicultural based education will be able to instill the values contained in pluralism, including humanism and democracy directly in schools between students and their friends and between teachers or students and their teachers. So it is hoped that educational institutions, especially educators, are able to design curricula and learning that lead to multicultural values, diversity of abilities, students' social backgrounds, religion, culture and others. In this way, students are expected not only to increase their knowing but also to increase their awareness so that they will always behave humanist, pluralist and democratic. Likewise, a teacher is expected not only to be able to master the material but also to be able to instill the values of this multicultural education.

\section{Multicultural Values}

According to Zakiyuddin Baidhawy, there are several characteristics to understand the standard of multicultural values in the context of religious education. These characteristics are: learning to live with differences, building

\footnotetext{
${ }^{24}$ Salmiwati, Urgensi Pendidikan Agama Islam..., p. 38

${ }_{25}$ Maslikhah, Quo vadis pendidikan multikultur:Rekonstruksi sistem pendidikan berbasis kebangsaan (diterbitkan atas kerjasama: Stain Salatiga Press \& JP Books,2007), p. 06.

${ }_{26}$ Zakiyuddin Baihawy, Pendiidkan Agama Berbasis Multikultural, ( Jakarta: PT. Gelora Aksara Pratama, 2006), p. 78-84

${ }^{27}$ HAR. Tilaar, Kekuasaan dan Pendidikan, Indonesia, (Magelang: Tera, 2003), p. 171.
} 
mutual trust. Take care of each other understanding, upholding mutual respect, openness in thinking, appreciation and intervention, conflict resolution and nonviolent reconciliation. ${ }^{26}$

H. A. R Tilaar recommends multicultural core values in general, namely:27

1) Democratic: democracy in education not only preserves the past value system but can also question and revise the value system. ${ }^{28}$

2) Pluralism: pluralism is the existence or tolerance of ethnic diversity or cultural groups in a society or country as well as the diversity of beliefs or attitudes in an agency, institution and so on.

3) Humanism: according to this view, individuals are always in the process of perfecting themselves, seeing humans as having high dignity, capable of self-determination, and capable of self-development by themselves. ${ }^{29}$

\section{Multicultural Values in Schools}

According to Baidhawi, the standard of multicultural values in the context of religious education, there are several characteristics. These characteristics are: learning to live with differences, building mutual trust. Maintaining mutual understanding, upholding mutual respect, openness in thinking, appreciation and intervention, conflict resolution. 30 and violent reconciliation.

From the above explanation, the authors conclude the universal values of multicultural education which will later become the focus of research are as follows:

a. Value Equality: Equality is a value that adheres to the principle that every individual has equal rights and positions in society. Therefore, every individual without exception has an equal opportunity to participate in social activities. In learning, the teacher will provide an understanding to students about all humans having equal rights and opportunities, there is no difference in socializing and learning, there is togetherness and acceptance. to differences between people. The Word of Allah SWT in the Al-Qur'an Surat Al Hujarat Verse 13.

b. Tolerance: Tolerance is an attitude of respecting other people who have differences. Like wise with Islam, a religion that has a high spirit of

${ }^{28}$ Ngainun Naim dan Achmad Sauqi, Pendidikan Multikultural Konsep dan Aplikasi, (ArRuzz Media: Yogyakarta, 2011), p. 61.

29 Haryanto Al-Fandi, Desain Pembelajaran yang Demokratis\&Humanis, (Ar-Ruzz Media: Yogyakarta, 2011), p. 71.

${ }^{30}$ Baidhawy, Pendidikan Agama Berwawasan Multikultural..., p. 78.

${ }^{31}$ Ainul Yaqin, Pendidikan Multikultural..., p. 59 
tolerance. Islam is just and moderate in the sense that it is neither extreme right nor extreme left. ${ }^{31}$ Students will be given an understanding of how the state of Indonesia is built on differences and inequalities, in accordance with our country's motto "Bhinneka Tunggal Eka", the Prophet Muhammad unites the mehajirin and the ansor. In accordance with the word of Allah SWT in the Al-Qur'an Surah Al Kafirun Verses 1-6.

c. Harmony Value: harmony broadly means an atmosphere of brotherhood and togetherness among the people, even though they differ in ethnicity, religion, race and class. ${ }^{32}$ With religious maturity, it is hoped that there will be religious harmony with different schools of thought. The basis of living in harmony is in accordance with the word of Allah SWT in the letter al hujurat verse $10 .{ }^{33}$

The core values of multicultural education are democracy, humanism, pluralism. As for multicultural education, the process of values instilled in the form of a way of life is respectful, sincere, tolerant of cultural diversity that lives in a pluralistic society. The hope is that students will be able to become a generation that upholds morality, discipline, humane care, and honesty in their daily behavior.

\section{Understanding Religious Culture}

According to Djamaludin Ancok and Fuat Nashori, religion is an institutionalized symbol system, belief system, value system, and behavior system, all of which center on issues that are living in as the most meaningful. ${ }^{34}$ Religion comes from the word religious which is an adjective of a religious noun. So that from various kinds of assumptions about religious then it is translated into religion or belief. While religion comes from the Sanskrit word. Meanwhile, other opinion states that religion is composed of two words, a which means no and gm which means to go and if they are combined to not go, remain in place, inherited from generation to generation. ${ }^{35}$

\footnotetext{
32 Murni Eva Rumapea, Kedewasaan Beragama Salah Satu Wujud Kerukunan Beragama, Jurnal Pendidikan Ilmu-Ilmu Sosial 2016, diakses 12 Juni 2017.

${ }^{33}$ Kemenag, Al-Qur'an Terjemah Bahasa Indonesia..., p. 517.

${ }_{34}$ Djamaludin Ancok dan Fuat Nashori Suroso, Psikologi Islam (Solusi Islam atas ProblemProblem Psikologi), (Yogyakarta: Pustaka Pelajar, 1995), p. 76.

35 H.M. Ridwan Lubis, Agama dan Perdamaian Landasan, Tujuan, dan Realitas Kebidupan beragama di Indonesia, (Jakarta: PT Gramedia Pustaka Utama, 2017), p. 01
} 
So having a religion is a tendency that cannot be avoided by humans. Even though the reason has limitations in understanding religious doctrines, humans are forced by reason to acknowledge religion.

\section{Culture (culture)}

Etymologically, the word culture comes from the root word culture which comes from Sangsakerta. From the single-Buddhist root, the plural is Buddhayah which means mind, mind, or mind. After getting the prefix and suffix, it becomes culture, which means things about the human mind. ${ }^{36}$

The term Culture is a foreign language, term which has the same meaning as culture, Culture comes from the word color which means managing or teaching, namely managing the land or farming. From the origin of this meaning, namely color and culture, it is defined as all human power and activities to manage and change the nature. ${ }^{37}$

Meanwhile, according to experts, it is as follows: Sir Edward B Taylor, uses the word culture to denote the whole complex of ideas and everything that humans produce in their historical experience. Including knowledge, beliefs, arts, morals, laws, habits, and other abilities and behaviors that humans acquire as members of society. ${ }^{38}$

Robert H. Lowie defines culture as everything that is obtained by individuals from society, including beliefs, customs, artistic norms, eating habits, skills that are acquired not because creativity itself is a legacy of the past through formal and non-formal education. ${ }^{39}$

Koentjaraningrat, culture is the whole system of ideas, actions, and human works in the context of community life which is made the property of humans by learning. 40

So from several definitions and meanings of culture and culture, it can be concluded that culture or culture is the result of human initiative which is making a habit of each individual or group.

\section{Elements of Culture}

Culture is not inherited biologically, but can only be obtained by learning as a community and /or members of society itself. Almost all human action is cultural. Herkovits said there are 4 (four) main elements of culture, namely

\footnotetext{
${ }^{6}$ Santri Sahar, Pengantar Antropologi: Integrasi Ilmu Dan Agama (Makassar: Cara Baca, 2015), p. 98

${ }^{37}$ Soerjono Soekanto, Sosiologi suatu Pengantar ( Jakarta: Rajawali Press,2012), p. 150

${ }^{38}$ Sir Edward B Taylor, Premitive Culture (London: Jhon Murry, 1870), p. 322

${ }^{39}$ Robert H. Lowie, Culture \& Ethnology ( Americana: D.C McMurtrie, 1917), p. 03
} 
technological tools, economic systems, family and political power. From this description, Herkovits explains the 4 (four) main elements of culture as follows: (a) The system of norms that allows cooperation between members of society in order to control the natural surroundings, (b) Economic organization, (c) Tools of institutions or officers for education, and keep in mind that the family is the main educational institution, (d) Military organizations. ${ }^{41}$

The views of experts regarding cultural elements tend to differ, but they both understand that culture is an integrated whole. Koentjariningrat states that there are 7 (seven) elements in culture that are universal based on the opinion of anthropologists, including: (a) Language, (b) Knowledge system, (c) Social organization, (d) Livelihood system, (f) Living equipment and technology systems, (g) religious systems, (h) art systems. ${ }^{42}$

\section{Religious Culture (Religious Culture)}

Relativity or religiosity can be manifested in various aspects of human life. Religious activity does not only occur when a person performs ritual behavior (worship), but also when he performs other activities driven by supernatural forces.

According to Clock \& Stark, there are five kinds of religious dimensions, namely: (a) Dimensions of belief which contain expectations where religious people cling to certain theological views and acknowledge the truth of the doctrine, (b) Dimensions of religious practice which include worship behavior, obedience, and things that people do to show commitment to their religion, (c) The experiential dimension, this dimension contains and pays attention to the fact that all religions contain certain expectations. (d) The dimension of religious knowledge which refers to the hope that religious people have at least a minimum amount of knowledge regarding the basics of belief, rites, scriptures and traditions (culture), (e) Relating to the dimension of religious knowledge which refers to the hope that religious people have at least a minimum amount of knowledge, among others, regarding the basics of tradition / culture. Tradition / culture has several functions, among others, as a forum for religious expression and a means of binding groups. ${ }^{43}$

${ }^{40}$ Koentjaraningrat, Kebudayaan, mentalitas dan pembangunan ( Jakarta: PT. Gramedia Pustaka Utama, 2004), p. 01

41 Herkovits, Dehomean Narrative A Cross-Culture Analysis ( America: Northwesten Universty Press, 1998), p. 81

42 Koentjaraningrat, Kebudayaan, mentalitas dan pembangunan .... , p. 7

${ }^{43}$ Muhaimin, Paradigma Pendidikan Islam, (Bandung: PT.Remaja Rosdakarya, 2001), p. 297 
IJIERM: Vol. 2 No. 1 Januari - April 2020

Religious Culture in this context means cultivating the values of Islamic Religion in school life, which aims to embody the values of Islamic Religion obtained by students from learning outcomes at school, so that they become an integral part of the daily behavior of students in the school environment and in the community.

Figure Chart 1 Religious Culture

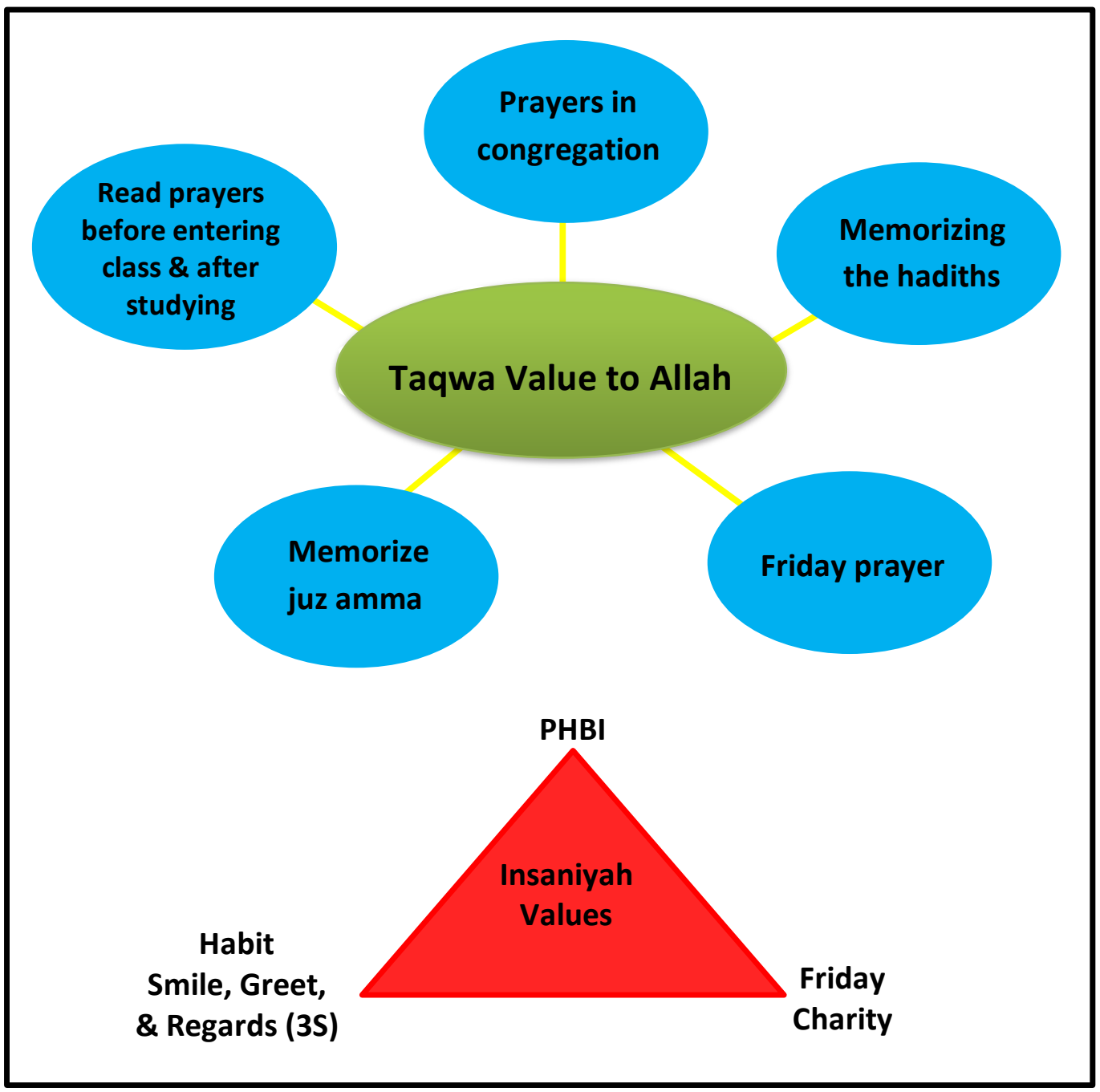

\section{RESEARCH METHODS}

This type of research is qualitative with a case study approach to understand the phenomena experienced by research subjects. For example behavior, perception, motivation, actions and others. Holistically and by means of description in the form of words and language in a specific natural context and by 
utilizing as a natural method. ${ }^{44}$ In this study, the researcher wanted to describe comprehensively about religious culture as a way to instill multicultural values of students in SD Islamic Global School Malang. A case study is a type of research conducted intensively, in detail and in depth on an organism (individual), institution or a particular phenomenon with a narrow area or subject. ${ }^{45}$ With this type of research, it is hoped that the research objectives can be achieved as planned by the researcher.

In the qualitative research paradigm, the researcher acts as the main instrument in the research. The position of the presence of researchers in a qualitative study is planning, implementing, collecting data, analyzing, reviewing data and the end of the research process, namely formulating conclusions. ${ }^{46}$

\section{DISCUSSION}

\section{A. Model of Religious Culture in SD-Islamic Global School Malang City}

The implementation of Religious Culture in SD-Islamic Global School Malang City has a background, namely to foster multicultural values by cultivating religious values. On the other hand, there is the development of a religious culture to form students who have good morals in accordance with the vision and mission of the SD-Islamic Global School Malang City.

The religious culture developed comes from the Al-Quran and Al-Hadith, as well as the vision and mission. The religious culture carried out at SD-Islamic Global School in Malang City originated from an agreement among school residents, especially the principal, the vice principal of the curriculum and student affairs section, and the Islamic religious education teacher. The religious values that exist in school are in the form of Divine values and Insaniyah values. Where these values have the goal of a relationship with God (Taqwa) and a relationship with fellow humans (Multicultural Values). The current era of globalization has had an impact and model on social growth in society. Today's global society is known for its open millennial society with more rational characteristics. Future oriented, open, respectful of time, creative and innovative. ${ }^{47}$

Religious Culture which is carried out at SD-Islamic Global School Malang City includes the following:

1) The values of piety, faith and piety in the form of prayer together in front of the class before entering class, praying before and after studying,

${ }^{44}$ Lexy J. Moleong, Metodologi Penelitian Kualitatif (Bandung: Remaja Rosdakarya, 2011), p. 
IJIERM: Vol. 2 No. 1 Januari - April 2020

praying before going out of class and riding a vehicle, dhuha prayers, dzuhur and am in congregation, Friday prayers in congregation and Friday ' at clean. Meanwhile, periodic religious activities include Eid al-Adha prayer and carbon, other holiday activities (PHBI) such as the commemoration of ${ }^{11}$

Mauled Nabi, Isra'mikraj and Pondok Romadhan. This piety value is in accordance with the word of God in surah al-ankabut: 45

2) Human Values. Which includes democracy, tolerance, caring, mutual respect, love and sharing. Habit of smiling, greeting, greeting (3S) and shaking hands when meeting teachers, Friday charity / giving. This is in accordance with the word of Allah in surah al-ashr verses 1-3.

The above religious values are the basis of religious, cultural activities which are developed and implemented at SD-Islamic Global School Malang City. With the hope that the value instilled in students is able to face this era of globalization. Social conditions related to multiculturalism and religion are very apprehensive and it is necessary to find solutions for children so that they are not carried away by the tendency of social problems such as neglecting the spiritual-religious aspects. So it is necessary to instill spiritual values from an early age, especially in school.

\section{B. Multicultural values internalized through religious culture in SD Islamic Global School Malang City}

Multicultural values internalized through religious culture to students at SDIslamic Global School Malang City are as follows.

1) The value of democracy, the inculcation of democratic values in schools is very important, this is to maintain the harmonization of the school environment, both the relationship between fellow students and the relationship between teachers and students and fellow teachers in schools, a democratic attitude is also used to motivate school members to form a personal personality. Positively, in carrying out activities both individually and in groups.

${ }^{45}$ Imam Gunawan, Metode Penelitian Kualitatif teori \& Praktik (Jakarta:Bumi Aksara, 2014), p. 115. 121.

46 Lexy J Moleong, Metodologi Penelitian Kualitatif (Bandung: Remaja Rosdakarya, 2006), p.

${ }^{47}$ Dalier Noer, Abuddin Nata, Manajement Pendidikan, (Jakarta:Pranada Media,2003).p. 91 
2) Tolerance value. The value of tolerance is a person's ability to respect the beliefs, opinions, habits and behavior of others that are different from ourselves. To form students to have an attitude of tolerance, a step or way is needed so that this goal can be achieved. Michale Borba provides an overview of ways and steps to implement tolerance in students, namely: a) Modeling and fostering tolerance in students, b). Fostering an appreciation for differences (motivation) c). Challenging stereotypes and not being prejudiced.

\section{The Process of Internalizing Multicultural Values through Religious culture in SD Islamic Global School Malang City}

The process of internalizing the multicultural values of students through religious culture at SD-Islamic Global School Malang City uses several aspects including aspects of giving good role models for students such as saying greetings, shaking hands, congregational prayer and so on. For more details, the researcher will explain below.

1) Exemplary aspects, exemplary aspects that exist in SD-Islamic Global School Malang City which are related to the process of instilling multicultural values through religious culture is to provide examples of tolerance, democracy, care and mutual help and mutual assistance carried out by all teachers, employees in SD-Islmic Global School Malang City.

2) Habit, can be defined as a way that can be used to get students to think, behave and act in accordance with the demands of Islamic teachings. As is done at SD-Islamic Global School in the process of internalizing multicultural values through students through a religious culture, namely the habit of smiling, greeting, smiling and shaking hands with teachers, praying in congregation, doing charity / giving which is called Friday charity. / invest and so on. The goal is for students to become accustomed to having a commendable attitude both to God (Taqwa) and to fellow humans (social / multicultural).

3) Through School Regulations, at SD-Islamic Global School Malang City school policy is a process of internalizing students' multicultural values through religious culture. Namely, the PAI development strategy in realizing school, religious culture has become a commitment and policy of school leaders, resulting in the birth of various regulations or policies that support the birth of various religious activities in schools that are socially oriented or internalizing multicultural values to students. Thus, this 
IJIERM: Vol. 2 No. 1 Januari - April 2020

approach is more "top down" in character, namely religious activities made on the initiative or instructions of the leadership so that it becomes a curriculum. This is motivated by the decline in multicultural values in society, so it is hoped that the cultivation of religious values will be able to protect students from this modern era, especially in the social field.

\section{CONCLUSION}

The religious culture model at SD-Islamic Global School Malang City is divided into two types, namely piety and human values. The value of piety to Allah in SD-Islamic Global School Malang City includes activities: dhuha, dhuhur and as prayers in congregation, Friday prayers in congregations at community mosques, prayers entering class, before studying and after studying, praying out of class and riding vehicles, memorizing short letters and hadiths that are used daily, and commemoration of Islamic Holidays (PHBI). Meanwhile, the human values that exist in SD-Islamic Global School Malang City include: Habit of smiling, greeting, greeting and shaking hands, doing charity Friday / giving, polite speaking.

There are two types of multicultural values internalized through religious culture at SD-Islamic Global School in Malang City, namely democratic values which are seen by habituation of group / congregational religious activities through dhuha, dzuhur and asr prayers in congregation, and take turns leading prayers in front of the class, as well as outside class when students want to enter their respective classes. And the value of tolerance, which is done by habituating religious activities such as Friday charity, the culture of smiling, greeting, smiling and shaking hands when meeting teachers and friends.

The process of internalizing the multicultural values of students through religious culture at SD-Islamic Global School Malang City is in three ways. First, by example. The exemplary process carried out by teachers and school employees has the aim that students can directly assess and imitate what is used by the teacher. Second, habituation. The aspects of habituation that are carried out include habituation of religious cultural activities, habituation of saying greetings, smiling, greeting and shaking hands when meeting teachers, habituating charity / infaq and carrying out religious activities in schools. And third, through SOP, this process aims to provide a deterrent effect for students who violate school regulations. The types of punishment applied included: reading Istighfar, writing Istighfar, not getting time to rest, and writing short letters. 
IJIERM: Vol. 2 No. 1 Januari - April 2020

\section{REFERENCES}

Al-Fandi, Haryanto, Desain Pembelajaran yang Demokratis \& Humanis, (Ar-Ruzz Media: Yogyakarta, 2011)

Ancok, Djamaludin, dan Fuat Nashori Suroso, Psikologi Islam (Solusi Islam atas Problem- Problem Psikologi), (Yogyakarta: Pustaka Pelajar , 1995)

Atmadi, A. dan Y. setyaningsih, (eds.), Pendidikan Nilai Memasuki Milenium Ketiga, (Yogyakarta: Kanisius, 2004 cet. 5,)

Baihawy, Zakiyuddin, Pendiidkan Agama Berbasis Multikultural, (Jakarta: PT. Gelora Aksara Pratama, 2006).

Banks, James A. Race, Culture and Education, (New York: Roudledge, 2006)

Borba, Michele, Membangun Kecerdasan Moral, (Jakarta: Gramedia Pustaka. 2008)

Fraenkel, J.R. How to teach about Values: an Analitic Approach, (New Jersey: Preteice Hall, inc.1975)

Gazalba, Sidi, Sistematika Filsafat, buku IV, (Jakarta: Bulan Bintang, 1978)

Gunawan, Imam, Metode Penelitian Kualitatif teori \& Praktik (Jakarta:Bumi Aksara, 2014)

Harahap, Ahmad Rivai. Multikulturalisme dan Penerapannya dalam pemeliharaan kerukunan Umat Beragama", 2004.

Hasyim, Umar, Toleransi dan Kemerdekaan Beragama dalam Islam sebagai Dasar menuju Dialog dan Kerukunan Antar Agama, (Surabaya: Bina Ilmu, 1991)

Herkovits, Dehomean Narrative A Cross-Culture Analysis ( America: Northwesten Universty Press, 1998)

Hidayatullah, Furqon, Pendidikan Karakter: Membangun Peradaban Bangsa, (Surakarta: Yuma Pustaka, 2010)

Koentjaraningrat, Kebudayaan, mentalitas dan pembangunan (Jakarta: PT. Gramedia Pustaka Utama, 2004)

Lowie, Robert H. Culture \& Ethnology ( Americana: D.C McMurtrie, 1917)

Lubis, H. M. Ridwan, Agama dan Perdamaian Landasan, Tujuan, dan Realitas Kehidupan beragama di Indonesia, Jakarta: PT Gramedia Pustaka Utama, 2017)

Mahfud, Choirul, Pendidikan Multikultural, (Yogyakarta: Pustaka Pelajar, 2009, cet.3)

Maslikhah, Quo vadis pendidikan multikultur:Rekonstruksi sistem pendidikan berbasis kebangsaan (diterbitkan atas kerjasama: Stain Salatiga Press \& JP Books, 2007)

Moleong, Lexy J, Metodologi Penelitian Kualitatif (Bandung: Remaja Rosdakarya, 2006) 2011)

Muhaimin, Paradigma Pendidikan Islam, (Bandung: PT.Remaja Rosdakarya, 2001) 
Muhajir, Noeng, Pendidikan Ilmu dan Islam, (Yogyakarta: Reka Sarasin, 1985)

Mulkhan, Abdul Munir, Kesalehan Multicultural Ber-Islam Secara Autentik-Kontekstual di Aras Peradaban Global, Pusat Study Agama Dan Peradaban(PSAP) Muhammadiyah, (Jakarta Pusat, 2005)

Naim, Ngainun, dan Achmad Sauqi, Pendidikan Multikultural Konsep dan Aplikasi, (ArRuzz Media: Yogyakarta, 2011)

Noer, Dalier, dan Abuddin Nata, Manajement Pendidikan, Jakarta:Pranada Media, 2003)

Pramasanti, Dhita, "Internalisasi Nilai-nilai keagamaan dalam membentuk komonikasi keluarga islami di era digital', Jurnal Interferensi, Vol. 12 no.01, Juni 2018

Ramayulis, Ilmu Pendidikan Islam, (Jakarta: KALAM MULIA, 2012)

Rumapea, Murni Eva, Kedewasaan Beragama Salab Satu Wujud Kerukunan Beragama, Jurnal Pendidikan Ilmu-Ilmu Sosial 2016, diakses 12 Juni 2017.

Sahar, Santri, Pengantar Antropologi: Integrasi Ilmu Dan Agama (Makassar: Cara Baca, 2015)

Sahlan, Asmaun, Mewnjudkan Budaya Religius di Sekolah: Upaya Mengembangkan PAI dari Teori ke Aksi,(Malang: UIN Malang Press, 2010)

Soediharto, Menuju Pendidikan Nasional yang Relevan dan Bermutu, (Jakarta: Balai Pustaka, 1993, cet. 4,)

Soekanto, Soerjono, Sosiologi suatu Pengantar ( Jakarta: Rajawali Press, 2012)

Soeroso, Andreas. Sosiologi 2 SMA kelas XI (Perpustaakan Nasional: Quadra, 2008)

Syam, Muhammad Nur, Pendidikan Filsafat dan Dasar Filsafat Pendidikan, (Surabaya: Usaha Nasional, t.t)

Tafsir, Ahmad, Filsafat Pendidikan Islami (Bandung: PT Remaja Rosdakarya, 2006)

Taylor, Sir Edward B. Premitive Culture (London: Jhon Murry, 1870)

Thoha, Chabib, Kapita Selekta Pendidikan Islam, (Yogyakarta: Pustaka Pelajar, 1996)

Tilaar, HAR. Kekuasaan dan Pendidikan, Indonesia, (Magelang: Tera, 2003)

Tim Redaksi kamus besar bahasa Indonesia Edisi kedua, Kamus Besar Bahasa Indonesia, (Jakarta: Balai Pustaka,1995), cet.4

Undang-Undang Sisdiknas Nomor 20 Tahun 2003, tentang Sistem Pendidikan Nasional, (Bandung: Citra Umbara, 2009)

Yamin, Moh. dan Vivi Aulia, Meretas Pendidikan Toleransi:Pluralisme dan Multikulturalisme sebuah keniscayaan peradaban, (Malang: Madani Media, 2011)

Yaqin, M. Ainul, Pendidikan Multikultural: cross-cultural understanding untuk demokrasi (Yogyakarta: Pilar Media, 2005)

Internet

https://www.alsofwah.or.id/cetakmujizat.php?id=131.

Https://www.google.co.id/amp/s/nasional .tempo.co/amp

Wawancara

Eni, Wawancara (Kota Malang, 27 Februari 2019)

Fahmi, wawancara (Kota Malang, 21 Februari 2019).

Susanto W awancara, (Kota Malang, 15 Desember 2018).

Tita Wawancara, (Kota Malang, 01 Maret 2019). 